\title{
Blood parasites in passerine birds from the Brazilian Atlantic Forest
}

\author{
Hemoparasitos em passeriformes da Mata Atlântica Brasileira \\ Fabiane Sebaio ${ }^{1}$; Érika Martins Braga ${ }^{2}$ Felipe Branquinho ${ }^{2}$; Alan Fecchio ${ }^{3}$ Miguel Ângelo Marini $^{4 *}$ \\ ${ }^{1}$ Programa de Pós-graduação em Ecologia, Conservação e Manejo da Vida Silvestre, Instituto de Ciências Biológicas - ICB, \\ Universidade Federal de Minas Gerais, UFMG \\ ${ }^{2}$ Departamento de Parasitologia, Instituto de Ciências Biológicas - ICB, Universidade Federal de Minas Gerais - UFMG \\ ${ }^{3}$ Programa de Pós-Graduação em Biologia Animal, Universidade de Brasília - UnB \\ ${ }^{4}$ Departamento de Zoologia, Instituto de Ciências Biológicas - ICB, Universidade de Brasília - UnB
}

Received February 8, 2011

Accepted November 23, 2011

\begin{abstract}
Parasites may lead bird species to extinction, affect host temporal and spatial population dynamics, alter community structure and alter individuals' social status. We evaluated blood parasite prevalence and intensity according to bird families and species, among 925 birds that were caught in 2000 and 2001, in the Atlantic Forest in the State of Minas Gerais, Brazil. We applied Giemsa staining to thin blood smears, to detect blood parasites. The birds ( $\mathrm{n}=15.8 \%)$ in 11 families, were infected by at least one parasite genus, especially Muscicapidae (28.3\%) and Conopophagidae (25\%). Among the 146 infected birds, Plasmodium was detected in all bird families and had the highest prevalence (54.8\%). Trypanosoma, Haemoproteus and microfilaria had lower prevalence rates (23.3, 23.3 and $2.1 \%$, respectively). Birds caught during the rainy season were more infected than birds caught during the dry season. The overall low prevalence of blood parasites in birds is similar to the patterns found elsewhere in the Neotropical region.
\end{abstract}

Keywords: Brazil, microscopy, parasites, Plasmodium, Trypanosoma, Haemoproteus.

\section{Resumo}

Parasitos podem levar espécies de aves à extinção, afetar as dinâmicas temporais e espaciais dos hospedeiros, alterar a estrutura de comunidades e o status social de indivíduos. Avaliou-se a prevalência e a intensidade de parasitos em famílias e espécies de 925 aves capturadas, entre 2000 e 2001, na Mata Atlântica de Minas Gerais. Foram coradas com Giemsa extensões de sangue para detectar parasitos hematozoários. As aves $(\mathrm{n}=15,8 \%) 11$ famílias estavam infectadas por pelo menos um gênero de parasito, especialmente Muscicapidae (28,3\%) e Conopophagidae (25\%). Entre as 146 aves infectadas, Plasmodium foi detectado em todas as famílias e possuiu a maior prevalência (54,8\%). Trypanosoma, Haemoproteus e microfilaria possuíram baixas prevalências (23,3, 23,3 e 2,1\%, respectivamente). Aves capturadas durante a estação chuvosa estavam mais infectadas do que aves capturadas durante a estação seca. A baixa prevalência geral de parasitos do sangue das aves é semelhante aos padróes encontrados em outras localidades da regiáo Neotropical.

Palavras-chave: Brasil, microscopia, parasitos, Plasmodium, Trypanosoma, Haemoproteus.

\section{Introduction}

Haematozoa, or blood parasites, may lead bird species to extinction (VAN RIPER III et al., 1986), and alter sexual selection and the evolution of plumage color (HAMILTON; ZUK, 1982; PRUETT-JONES et al., 1990; KIRKPATRICK; RYAN, 1991). Infected individuals may be more susceptible to predators and less able to establish territories (ANDERSON; MAY, 1979). Parasite infections may determine avian death, but the cause of mortality

\footnotetext{
*Corresponding author: Miguel Ângelo Marini

Departamento de Zoologia - ICB, Universidade de Brasília - UnB,

CEP 70910-900, Brasília, DF, Brazil

e-mail: marini@unb.br
}

is usually identified a posteriori (McCALLUM; DOBSON, 1995). Moreover, pathogens are usually considered to be regulators of host population size.

Several studies focusing on occurrence, prevalence or incidence of blood parasites in birds have been conducted (YOUNG et al., 1993; GILARDI et al., 1995). Within the Apicomplexa phylum, Haemoproteus, Leucocytozoon and Lankesterella are the most prevalent genera infecting birds (BENNETT; BORRERO, 1976; ATKINSON; VAN RIPER III, 1991). Plasmodium has received most attention, including in relation to its evolutionary ecology (PAUL et al., 2003), but its distribution has not been fully 
documented yet. Plasmodium, Haemoproteus and Leucocytozoon have been recorded in several parts of the world, with the exception of Antarctica, where the low temperatures do not allow the vectors to survive (FRIEND; FRANSON, 1999). As well as in the Apicomplexa, the blood parasite Trypanosoma has also been reported in a wide array of bird hosts (PEIRCE, 1989). However, there is still little evidence to show that this parasite genus is pathogenic in birds (BAKER, 1976).

Most studies on the prevalence of blood parasites in birds have been conducted in the Neartic region (GREINER et al., 1975; KIRKPATRICK; SUTHERS, 1988) and few have been performed in the Neotropical region (DURRANT et al., 2006; FECCHIO et al., 2007; FECCHIO et al., 2011). Some studies have found high prevalence of Haemoproteus and low prevalence of Plasmodium in the state of São Paulo, Brazil (BENNETT; SOUZA, 1980; WOODWORTH-LYNAS et al., 1989). However, very low prevalence values have been found in the Cerrado (savanna) region of central Brazil (FECCHIO et al., 2007, 2011). The prevalence of blood parasites and the diversity of haematozoan haplotypes have been found to be higher in Guyana than in Uruguay (DURRANT et al., 2006). Although no relationship has been found between blood parasite diversity and latitude in Chile, a positive relationship between prevalence and latitude has been shown for Leucocytozoon, and negative relationships for Haemoproteus, Plasmodium and mixed infections (MERINO et al., 2008). Considering the poor knowledge about blood parasitism among wild birds in Brazil, this study had the aims of evaluating the prevalence of avian blood parasites in several areas of the Atlantic Forest, and estimating their occurrence and intensities in different seasons.

\section{Materials and Methods}

Between August and October 2000 and between June and November 2001, birds were caught in Brazilian Atlantic forest fragments, in the following areas of the state of Minas Gerais: 1) Sossego Forest Private Natural Heritage Reserve (Reserva Particular do Patrimônio Natural Mata do Sossego; RPPN Mata do Sossego), located in the municipality of Simonésia (20 $07^{\prime} \mathrm{S}$; $\left.42^{\circ} 00^{\prime} \mathrm{W}\right)$; 2) Dark Forest Farm (Fazenda da Mata Escura), located on the left bank of the Jequitinhonha River ( $16^{\circ} 20^{\prime} \mathrm{S}$; $41^{\circ} 00^{\prime}$ W); 3) Brigadeiro Range State Park (Parque Estadual Serra do Brigadeiro; PESB), located within the Mantiqueira mountain range (Serra da Mantiqueira) (20 20' and $21^{\circ} 00^{\prime} \mathrm{S}$; $42^{\circ} 20^{\prime}$ and $42^{\circ} 40^{\prime}$ W): 4) Jambreiro Forest Private Natural Heritage Reserve (Reserva Particular do Patrimônio Natural Mata do Jambreiro; RPPN Mata do Jambreiro), located in the municipality of Nova Lima (195 58' S; 435’ W); 5) Santana Farm (Fazenda Santana), located on the left bank of the Jequitinhonha River (16 $05^{\circ} \mathrm{S}$; $\left.40^{\circ} 02^{\prime} \mathrm{W}\right)$; and 6) Caratinga Private Natural Heritage Reserve (Reserva Particular do Patrimônio Natural de Caratinga; RPPN de Caratinga), located in the municipality of Caratinga (20 06' S; $\left.41^{\circ} 21^{\prime} \mathrm{W}\right)$ (Figure 1). Birds were caught in two forest fragments in each of these areas: one large fragment (>1000 ha) and one small fragment (up to $30 \mathrm{ha}$ ). The fragments were isolated from

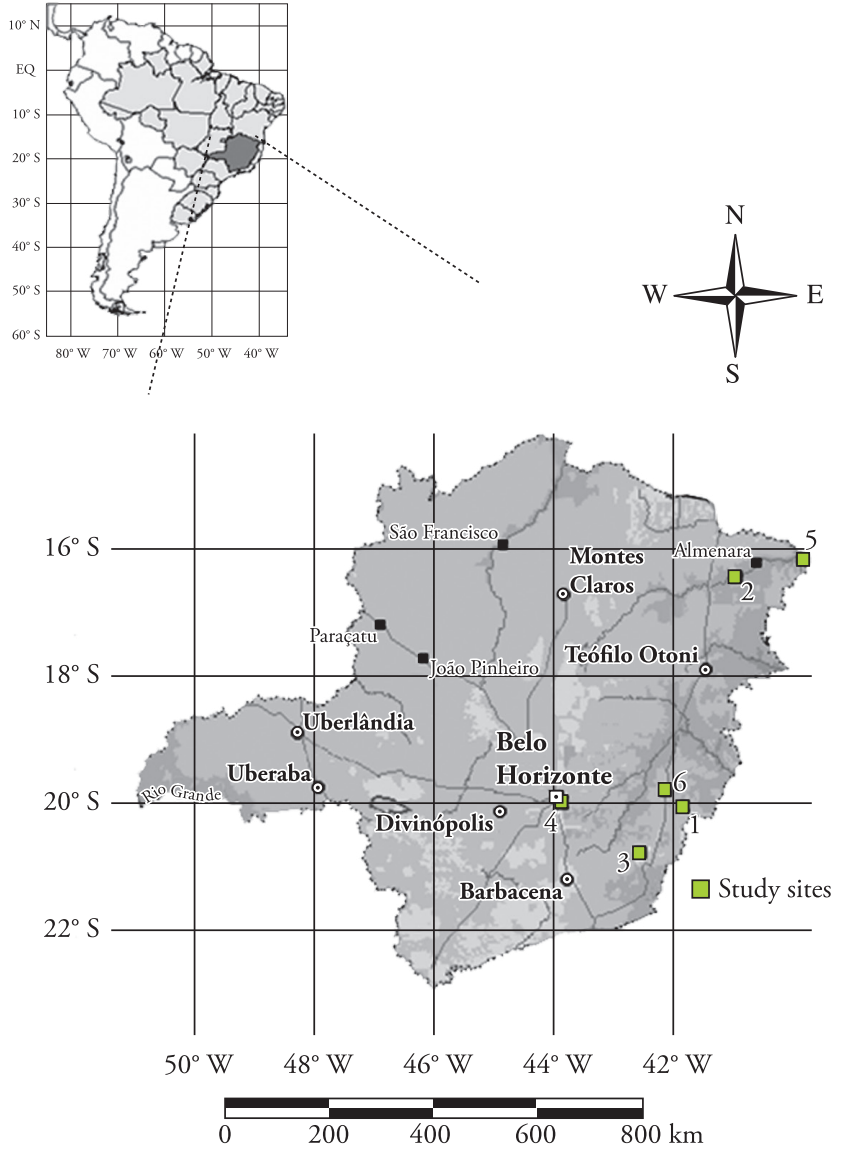

Figure 1. Study sites visited in the Brazilian Atlantic Forest domain within the state of Minas Gerais. 1) Sossego Forest Private Natural Heritage Reserve (Simonésia); 2) Dark Forest Farm (Jequitinhonha); 3) Brigadeiro Range State Park (Ervália); 4) Jambreiro Forest Private Natural Heritage Reserve (Nova Lima); 5) Santana Farm (Salto da Divisa); 6) Caratinga Private Natural Heritage Reserve (Caratinga). Map source: SOS Atlantic Forest Foundation (Fundação SOS Mata Atlântica), INPE.

each other or from any other forested area by at least $1 \mathrm{~km}$ of open land, mostly used for crops and pasture.

The birds were caught using up to 20 mist nets, which were left open from sunrise until 5:00 PM, with a mean total of 640 mist-net hours for each area. The birds were identified using field guides. The individuals that were caught were then banded with a metal ring from the Brazilian birding agency (CEMAVE/IBAMA), to ensure that we were not sampling the same individual twice. The birds were released after banding and after blood samples had been collected in order to prepare the thin blood smears. The species nomenclature used followed the prescriptions of the Brazilian Ornithological Records Committee (Comitê Brasileiro de Registros Ornitológicos) (CBRO, 2007), and the family nomenclature followed Comitê Brasileiro de Registros Ornitológicos (2006), so as to allow statistical analyses, because of the small samples sizes of several families.

In the field, we prepared one thin blood smear from each bird, using disposable lancets to make a small perforation in the left tarsus to collect a drop of blood. The smears were air dried and 
fixed with methanol. They were then stained with Giemsa solution in buffered water ( $\mathrm{pH} 7.2-7.4$ ), diluted at 1:10, in the Malaria Laboratory of the Federal University of Minas Gerais (UFMG).

We searched for blood parasites in the blood smears using an optical microscope (Olympus $3 \mathrm{H}$ ). We inspected at least two hundred fields on each smear, and the number of parasitized cells or the number of parasites was counted at $1,000 \times$ magnification under oil immersion.

We estimated three blood parasite infection parameters: prevalence, mean intensity and relative intensity (MARGOLIS et al., 1982). We used Spearman rank correlations to evaluate the relationships between blood parasite prevalence rates and mean and relative intensities for species or families with prevalence values differing from zero. We used Kruskal-Wallis to test for differences in parasite intensities among months and between the dry season (June, July, August and September) and rainy season (October and November). This test was also used to compare the infection intensity between the dry and rainy seasons, considering each parasite separately. We used a chi-square test for pairs of independent samples to ascertain whether the prevalence rates for parasite genera were independent between the seasons. We considered statistical differences to be significant at the 0.05 level. All statistical analyses were run using the STATISTICA (version 5.1), MINITAB or EPIINFO (version 6.0) computer packages.

\section{Results}

We analyzed 925 birds belonging to 109 species and 11 families (Table 1). A total of 146 birds (15.8\%) from 62 species and all 11 families (Figure 2) had at least one parasite specimen of Plasmodium, Trypanosoma, Haemoproteus or microfilaria. The total prevalence values for these four parasites were $9.2,3.8,3.2$ and $0.03 \%$, respectively (Table 1). Among the 146 infected individuals, we observed the following prevalence rates: Plasmodium (54.8\%), Trypanosoma (23.3\%), Haemoproteus (23.3\%) and microfilaria (2.1\%). For several birds, this was the first report showing them to be new hosts for some blood parasites. Of the 62 bird species parasitized, 31 were new host records for Plasmodium, eight for Haemoproteus and two each for Trypanosoma and microfilaria (Table 1).

The parasite prevalence rates were not homogeneous among the bird families. Plasmodium was detected in all 11 bird families, with very high incidence in Muscicapidae (24.5\%). The prevalences of Trypanosoma and Haemoproteus were low, compared with the prevalence of Plasmodium. Trypanosoma was detected in 14 species of eight bird families. Conopophagidae was the bird family with the highest prevalence (13.8\%) of Trypanosoma, whereas Troglodytidae and Dendrocolaptidae had no birds infected with Trypanosoma. Haemoproteus was detected in only five families: Tyrannidae ( $\mathrm{n}=226 ; 9.7 \%)$, Emberizidae ( $\mathrm{n}=173 ; 2.3 \%$ ), Muscicapidae ( $\mathrm{n}=53 ; 1.9 \%)$, Conopophagidae ( $\mathrm{n}=80 ; 1.3 \%)$ and Thamnophilidae $(\mathrm{n}=165 ; 1.2 \%)$ (Table 1$)$.

The bird families and species with the highest parasite prevalence also generally had the highest parasite intensity. Prevalence was positively and significantly correlated with relative intensity for all three parasites: Plasmodium $(\mathrm{n}=11 ; \mathrm{r}=0.998$; $\mathrm{p}<0.001)$,
Trypanosoma $(\mathrm{n}=9 ; \mathrm{r}=0.989 ; \mathrm{p}<0.001)$ and Haemoproteus $(\mathrm{n}=5$; $\mathrm{r}=0.983 ; \mathrm{p}=0.026$ ). However, the correlation between specific prevalence and mean intensity was positive and significant for the bird families infected with Plasmodium ( $\mathrm{n}=11$ bird families; $\mathrm{r}=0.768 ; \mathrm{p}=0.001)$, but was not significant for Trypanosoma $(\mathrm{n}=9 ; \mathrm{r}=0.002 ; \mathrm{p}=0.996)$ or Haemoproteus $(\mathrm{n}=5 ; \mathrm{r}=0.290$; $\mathrm{p}=0.255)$.

Prevalence and mean parasite intensity did not show any correlation at the species level: Plasmodium ( $\mathrm{n}=48$ bird species; $\mathrm{r}=0.137 ; \mathrm{p}=0.351)$, Trypanosoma $(\mathrm{n}=14 ; \mathrm{r}=0.432 ; \mathrm{p}=0.123)$ and Haemoproteus $(\mathrm{n}=17 ; \mathrm{r}=-0.090 ; \mathrm{p}=0.724)$. However, prevalence and relative parasite intensity were significantly correlated for Plasmodium ( $\mathrm{n}=48 ; \mathrm{r}=0.546 ; \mathrm{p}<0.001)$ and Trypanosoma ( $\mathrm{n}=14 ; \mathrm{r}=0.928 ; \mathrm{p}<0.001)$, but not for Haemoproteus $(\mathrm{n}=17$; $\mathrm{r}=0.436 ; \mathrm{p}=0.079)$.

The prevalence of parasitism was higher during the rainy months than during the dry months sampled. The rainy months had significantly $\left(\chi^{2}=9.9 ; \mathrm{p}=0.002\right)$ higher numbers of infected birds (618 individuals analyzed, $21.2 \%$ prevalence) than the dry months (307 individuals analyzed, 13\% prevalence). However, the prevalence varied greatly within the dry season, with the highest prevalence occurring in July ( $\mathrm{n}=78$ birds sampled; $33.3 \%$ parasitized) (Figure 3). September was the month with most birds sampled $(\mathrm{n}=302)$, but with the lowest parasite prevalence $(6.9 \%)$. The prevalence of Plasmodium varied irregularly along the months (Figure 4), being highest in July ( $\mathrm{n}=78$ birds sampled; $25.6 \%$ infected) and lowest in June ( $\mathrm{n}=38 ; 2.6 \%)$. However, no difference was detected between the dry months $(\mathrm{n}=51 ; 8.4 \%)$ and rainy months $(\mathrm{n}=34 ; 10.8 \%)$ in relation to prevalence $\left(\chi^{2}=1.15\right.$; $\mathrm{p}=0.28)$ or intensity $(\mathrm{H}=14.90 ; \mathrm{p}=0.136)$. Trypanosoma had the highest prevalence values in July and August and the lowest in the other months. There was no significant difference $\left(\chi^{2}=0.80\right.$; $\mathrm{p}=0.370)$ between the dry months $(\mathrm{n}=26 ; 4.3 \%)$ and the rainy months $(\mathrm{n}=9 ; 2.8 \%)$. For Haemoproteus, there was no significant difference $(\mathrm{H}=6.44 ; \mathrm{p}=0.27)$ in parasite intensity between the dry and the rainy months (Figure 4). Haemoproteus had low prevalence in all the months sampled, except in November $(\mathrm{n}=100 ; 23 \%)$. Comparing the two seasons, dry $(\mathrm{n}=4 ; 0.70 \%)$ and rainy $(\mathrm{n}=26 ; 8.2 \%)$, there was significantly higher prevalence $\left(\chi^{2}=35.63 ; \mathrm{p}<0.001\right)$ and higher parasite intensity $(\mathrm{H}=38.16$; $\mathrm{p}<0.001$ ) in the rainy season than in the dry season (Figure 4).

\section{Discussion}

Birds from most Neotropical regions seem to have low blood parasite prevalence rates, independent of the type of habitat or region (WHITE et al., 1978; FECCHIO et al., 2007, 2011). Our study showed that the overall blood parasite prevalence was 15.8\% among 925 birds sampled, similar to other Neotropical areas (WHITE et al., 1978). A study on the prevalence of parasites in birds from several habitats, including open areas, in southeast Brazil, found similar prevalence values for different habitats (WOODWORTH-LYNAS et al., 1989). Similarly, the prevalence values for blood parasites in passerines from several habitats (capoeira, 'terra firme' forest and várzea) in the Brazilian Amazon region were low (10\%) (LAINSON et al., 1970). 
Table 1. Total number of birds examined, total number of infected birds and number of birds infected by each blood parasite in the Brazilian Atlantic Forest sites of the state of Minas Gerais between 2000 and 2001.

\begin{tabular}{|c|c|c|c|c|c|c|}
\hline \multirow[t]{2}{*}{ Bird taxa } & \multirow{2}{*}{$\begin{array}{c}\text { No of birds } \\
\text { examined }\end{array}$} & \multirow{2}{*}{$\begin{array}{c}\text { No of infected } \\
\text { birds }\end{array}$} & \multicolumn{4}{|c|}{$\mathrm{No}^{0}$ of infected birds according to parasite taxa ${ }^{2}$} \\
\hline & & & Haem. & Plasm. & Tryp. & Micro. \\
\hline Mackenziaena leachii ${ }^{1}$ & 1 & 1 & & 1 & & \\
\hline Mackenziaena severa & 1 & 0 & 1 & & & \\
\hline Thamnophilus pelzelni & 33 & 4 & & 2 & & 1 \\
\hline Thamnophilus caerulescens ${ }^{1}$ & 27 & 6 & & 3 & 3 & \\
\hline Thamnophilus ambiguus & 4 & 0 & & & & \\
\hline Dysithamnus plumbeus ${ }^{1}$ & 9 & 1 & & 1 & & \\
\hline Myrmotherula gularis & 1 & 0 & & & & \\
\hline Formicivora serrana & 2 & 0 & & & & \\
\hline Drymophila ferruginea & 4 & 0 & & & & \\
\hline Drymophila ochropyga ${ }^{1}$ & 8 & 1 & & 1 & & \\
\hline Myrmeciza loricata ${ }^{I}$ & 10 & 2 & & 1 & 1 & \\
\hline Myrmeciza ruficauda & 1 & 0 & & & & \\
\hline Chamaeza campanisona $a^{1,3}$ & 1 & 1 & & 1 & 1 & \\
\hline Conopophaga melanops ${ }^{1}$ & 7 & 2 & 1 & 1 & & \\
\hline Conopophaga lineata & 73 & 18 & & 9 & 11 & \\
\hline Dendrocincla turdina ${ }^{1}$ & 8 & 1 & & 1 & & \\
\hline Sittasomus griseicapillus ${ }^{1}$ & 13 & 2 & & 2 & & \\
\hline Xiphocolaptes albicollis $^{1}$ & 2 & 1 & & 1 & & \\
\hline Dendrocolaptes platyrostris & 2 & 0 & & & & \\
\hline Lepidocolaptes squamatus & 2 & 0 & & & & \\
\hline Synallaxis cinerea & 1 & 0 & & & & \\
\hline Synallaxis frontalis ${ }^{1}$ & 9 & 2 & & 2 & & \\
\hline Synallaxis cinerascens $^{I}$ & 3 & 1 & & 1 & & \\
\hline Synallaxis scutata & 2 & 0 & & & & \\
\hline Phacellodomus rufifrons & 1 & 0 & & & & \\
\hline Anabazenops fuscus ${ }^{1}$ & 11 & 1 & & 1 & & \\
\hline Syndactyla rufosuperciliata & 4 & 1 & & & 1 & \\
\hline Philydor lichtensteini & 1 & 0 & & & & \\
\hline Philydor rufum ${ }^{1}$ & 8 & 2 & & 2 & & \\
\hline Automolus leucophthalmus & 6 & 1 & & 1 & 1 & \\
\hline Heliobletus contaminatus & 1 & 0 & & & & \\
\hline Lochmias nematura $^{1}$ & 11 & 1 & & 1 & 1 & \\
\hline Myiopagis viridicata ${ }^{1}$ & 2 & 1 & & 1 & & \\
\hline Myiopagis caniceps ${ }^{1}$ & 2 & 1 & 1 & & & \\
\hline Phaeomyias murina ${ }^{1}$ & 2 & 1 & & & & \\
\hline Elaenia obscura ${ }^{1}$ & 4 & 1 & & 2 & & \\
\hline Euscarthmus meloryphus & 2 & 0 & & 1 & & \\
\hline
\end{tabular}

${ }^{1}$ New host record, ${ }^{2}$ Haem. $=$ Haemoproteus $;$ Plasm. $=$ Plasmodium; Tryp. $=$ Trypanosoma $;$ Micro $=$ Microfilaria,${ }^{3}$ One bird with double infection by Haemoproteus and Trypanosoma,${ }^{4}$ One bird with double infection by Plasmodium and Trypanosoma. 
Table 1. Continued...

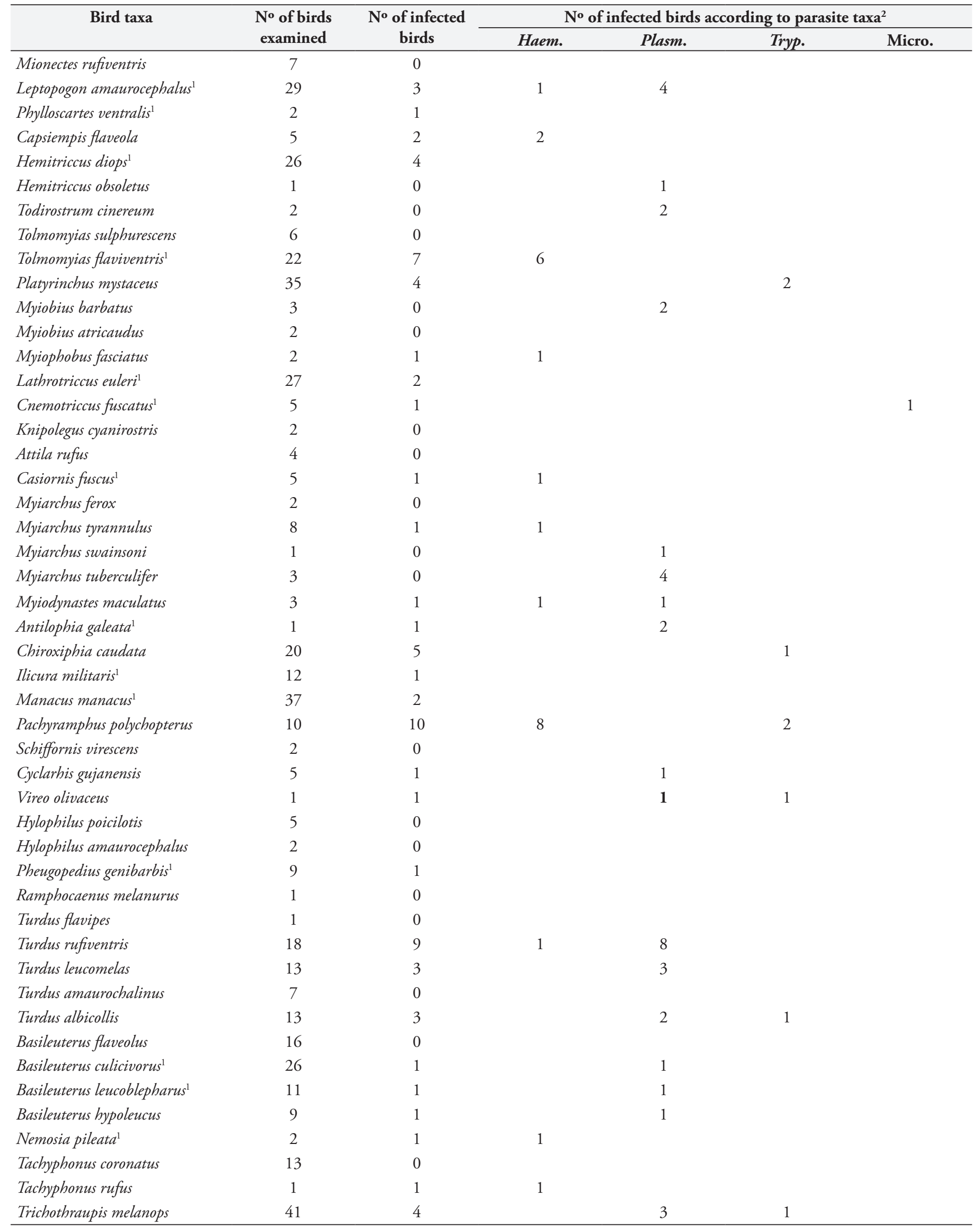

${ }^{1}$ New host record, ${ }^{2}$ Haem. $=$ Haemoproteus $;$ Plasm.$=$ Plasmodium $;$ Tryp. $=$ Trypanosoma $;$ Micro $=$ Microfilaria,${ }^{3}$ One bird with double infection by Haemoproteus and Trypanosoma, ${ }^{4}$ One bird with double infection by Plasmodium and Trypanosoma. 
Table 1. Continued...

\begin{tabular}{|c|c|c|c|c|c|c|}
\hline \multirow[t]{2}{*}{ Bird taxa } & \multirow{2}{*}{$\begin{array}{c}\text { No of birds } \\
\text { examined }\end{array}$} & \multirow{2}{*}{$\begin{array}{c}\text { No of infected } \\
\text { birds }\end{array}$} & \multicolumn{4}{|c|}{$N^{\circ}$ of infected birds according to parasite taxa ${ }^{2}$} \\
\hline & & & Haem. & Plasm. & Tryp. & Micro. \\
\hline Habia rubica & 6 & 0 & & & & \\
\hline Tangara desmaresti & 6 & 2 & 1 & 1 & & \\
\hline Tangara cyanoventris ${ }^{1}$ & 1 & 1 & 1 & & & \\
\hline Conirostrum speciosum & 1 & & 0 & & & \\
\hline Haplospiza unicolor ${ }^{I}$ & 7 & & 1 & 1 & & \\
\hline Tiaris fuliginosus & 3 & & 1 & 1 & & \\
\hline Arremon flavirostris & 2 & & 0 & & & \\
\hline Arremon franciscanus & 2 & & 0 & & & \\
\hline Arremon cf. semitorquatus & 2 & & 0 & & & \\
\hline Saltator maximus & 1 & & 1 & 1 & & \\
\hline Total & 925 & 146 & 31 & 80 & 34 & 3 \\
\hline Frequencies & & 15.8 & 3.4 & 8.7 & 3.7 & 0.3 \\
\hline
\end{tabular}

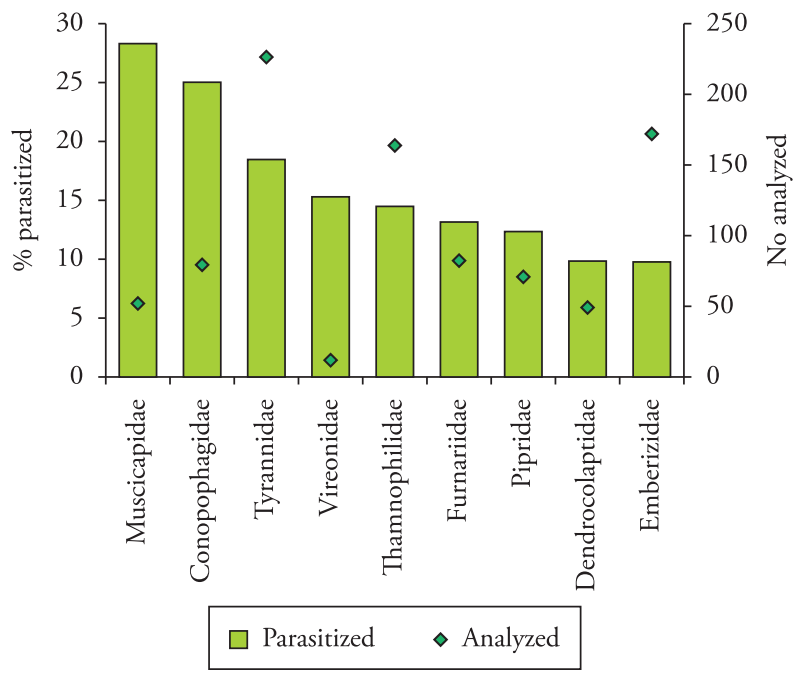

Figure 2. Total prevalence of parasitized birds and number of individuals sampled according to bird family (minimum of 13 individuals per family) in the Atlantic Forest, state of Minas Gerais, during 2000 and 2001.

It is difficult to identify nematode microfilariae at species level because of their high degree of morphological and morphometric similarities (McKEAND, 1998). Sehgal et al. (2005), for example, found eight forms of microfilaria in 12 African passerines based on morphological characteristics, but they were not able to assign them with certainty to any species. Similarly, Silveira et al. (2010) reported on two microfilarial forms from central Brazil, also with insufficient information to allow the identification of the specimens. However, one filarial species of Splendidofilariinae, Cardiofilaria pavlovskyi, has been reported in several birds, including Passeriformes (ANDERSON, 2000).
Plasmodium was the most prevalent parasite genus, and was detected in $9.2 \%$ of the 925 individuals sampled. This pattern is the rule for most Neotropical regions (WHITE et al., 1978; FECCHIO et al., 2007). However, Haemoproteus was the most prevalent parasite, infecting $38.9 \%$ of the birds sampled in a region in southeastern Brazil, whereas in our study, this parasite was 10 times less prevalent than what they found (WOODWORTHLYNAS et al., 1989). One explanation might be related to the fact that our study was restricted to forest birds of the order Passeriformes. Columbidae, for example, which is the most important host of Haemoproteus, was not considered in our study. Moreover, these two studies differed in relation to the time of the year when blood samples were taken in the Atlantic Forest region, and the authors did not mention the level of disturbance in their study sites, a factor that could also explain part of the differences in the samples that were collected. Nonetheless, the prevalence of both of these blood parasites varied considerably among the bird families and species that we studied. The reasons for these differences are unknown, but might involve the behavioral and ecological traits of the species. These bird-specific characteristics, such as type of nest constructed and reproductive behavior, might facilitate or prevent contact between birds and their vectors (MARINI et al., 1996; FECCHIO et al., 2011). Interspecies differences between blood parasites in terms of parasitemia might be influenced by the distribution of habitat-dependent vectors, at both micro and macro habitat scale (GARVIN; REMSEN, 1997; PIERSMA, 1997). Host specificity and host-parasite co-evolution are also factors that can affect parasite prevalence (WOODWORTHLYNAS et al., 1989). The detection of Plasmodium in all 11 bird families suggests that the genus is not host-specific, as has also been found by Bennett et al. (1982). However, Haemoproteus is more host-specific and is restricted to some species of bird families (FALLIS et al., 1974; ATKINSON et al., 1986). Trypanosoma was 


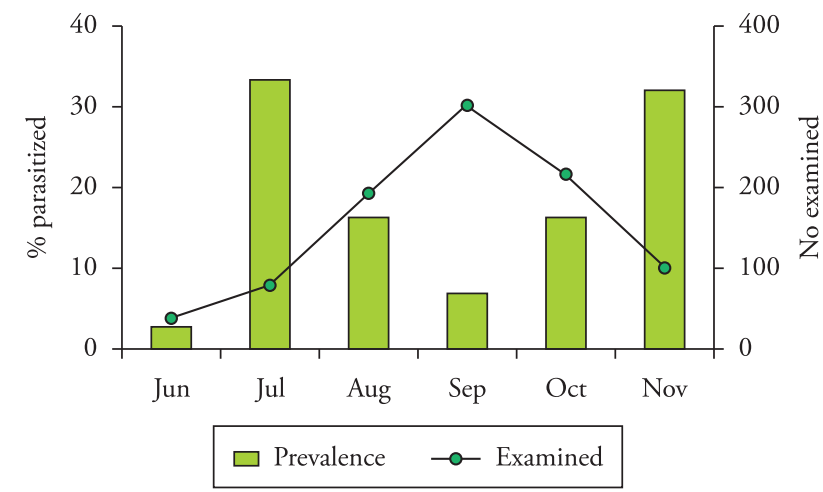

Figure 3. Percentage of individuals parasitized for each month sampled in the Atlantic Forest, state of Minas Gerais, during 2000 and 2001.

found in a small percentage of infected birds in spite of having a wide variety of vectors (PEIRCE, 1989). Its detection is difficult because of its low parasitemia and high polymorphism levels, which might explain the low prevalence that we found.

Prevalence and parasite intensity were positively correlated at both family and species levels. This has also been found for bird ectoparasites (PRUETT-JONES et al., 1991; MARINI et al., 1996). Factors relating to gender, age structure, behavior, season of the year and body condition of the populations studied might be important in explaining the parasitism levels. For example, birds with high infection by Plasmodium and Haemoproteus might exhibit signs such as appetite loss, apathy, shortness of breath and weakness in one or both legs (FRIEND; FRANSON, 1999). On the other hand, some studies have shown that low levels of parasitemia in the blood or tissue of a bird stimulate some protection against infection (WILSON et al., 2002). Thus, some birds might not show signs of diseases, but keep an infection, thus allowing the parasite population to survive through the dry season when vector populations are low (FRIEND; FRANSON, 1999).

Some blood parasites might change their loads or occur seasonally in the Atlantic Forest birds. In general, we found fewer parasites during the dry season than during the rainy season, even though the sample sizes were better during the rainy season. This pattern was due to the high prevalence of Haemoproteus during the rainiest months. Lower blood parasite prevalence during the dry season than during the rainy season was found in forest birds from Costa Rica and Jamaica (BENNETT et al., 1980; YOUNG et al., 1993). This pattern is in agreement with the North American model, in which it was proposed that blood parasite recurrence would be seen during the reproductive season (BEAUDOIN et al., 1971). The low prevalence during the dry months, a period when most birds are not reproducing, occurs mostly in tropical areas (BENNETT et al., 1991). During the reproductive season, nestlings still lack feathers and are more vulnerable to vectors and, thus, have high seasonal transmission. When we analyzed the results on a monthly basis, however, we detected similar peaks in both the seasons. This can be explained by the fact that even though all the data were gathered within the Atlantic Forest biome, they came from six different localities in the state of Minas Gerais. Data gathering in the same area throughout the year would enable better evaluation of this pattern.
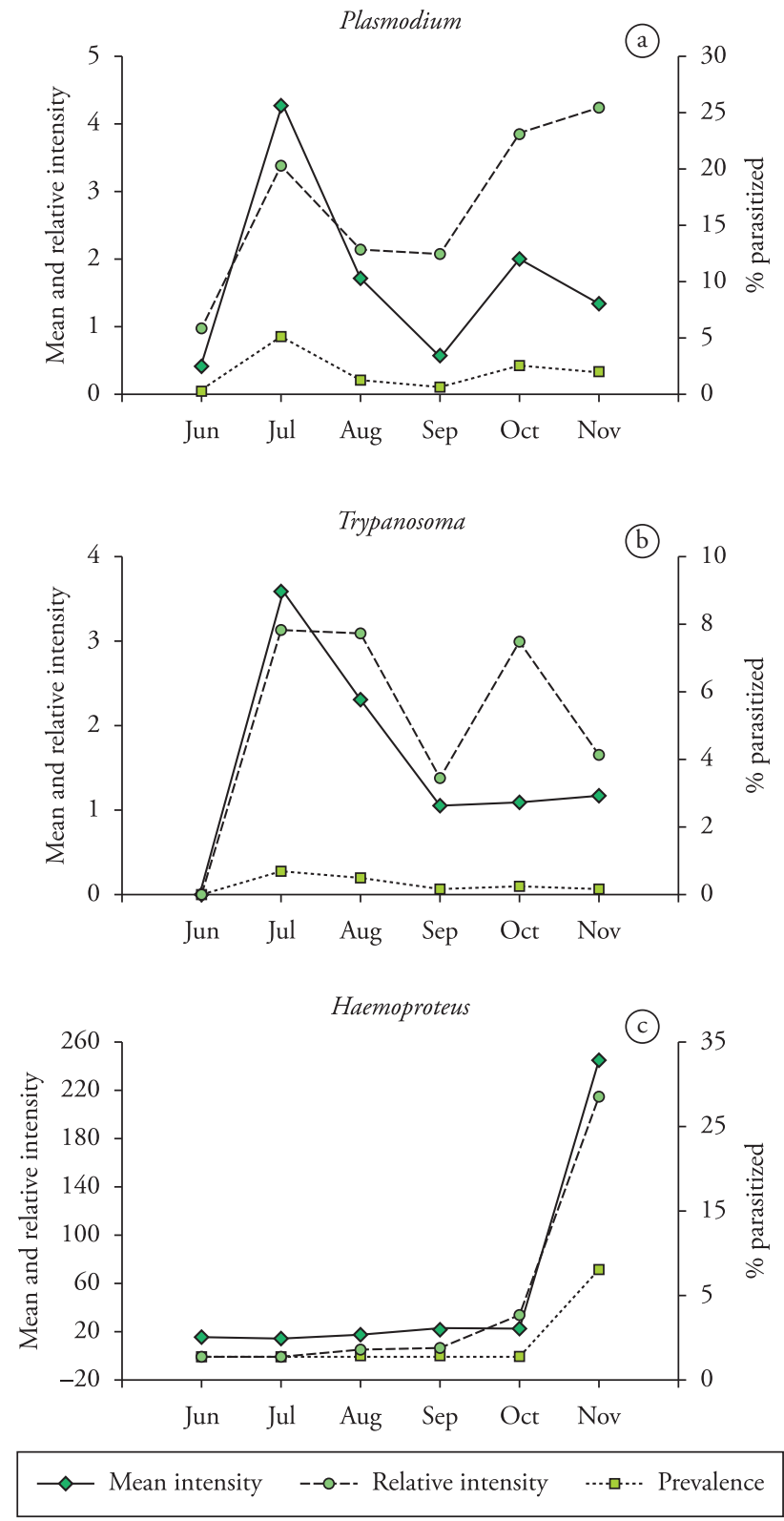

Figure 4. Parasite intensity and percentage of individuals parasitized for each month in the Atlantic Forest, state of Minas Gerais, during 2000 and 2001.

Overall, this study revealed that Atlantic Forest birds might be infected by several blood parasites at levels similar to what has been found in other Neotropical regions. The findings of differences in prevalence rates among hosts and for different parasites, and of temporal variation in prevalence values, reveal that blood parasite-bird interactions are very complex and poorly understood. Long-term population and community-based studies are required at both local and regional scales. The high number of new host species described in this study reflects the scarcity of studies of bird parasites in Brazil. We found more new hosts in bird families with more species sampled. This constitutes evidence of the need to acquire more knowledge of blood parasite bird hosts and their ecology and behavior. 


\section{Acknowledgements}

CNPq granted a scholarship to FS and a research grant and fellowship to MÂM. Owners and administrators allowed our study on their properties or in their conservation units. IBAMA gave banding/collecting authorization. Prof. Múcio Flávio Ribeiro provided laboratory support. Leonardo Lopes and Alexandre Fernandes provided invaluable assistance during data gathering in the field.

\section{References}

Anderson RC. Nematode parasites of vertebrates: their development and transmission. New York: CABI Publishing; 2000. http://dx.doi. org/10.1079/9780851994215.0000

Anderson RM, May RM. Population biology of infectious diseases, part I. Nature 1979; 280: 361-367. PMid:460412. http://dx.doi. org/10.1038/280361a0

Atkinson CT, Van Riper III C. Pathogenicity and epizootiology of avian haematozoa: Plasmodium, Leucocytozoon, and Haemoproteus. In: Loye JE, Zuk M. Bird-Parasite interactions: ecology, evolution and behaviour. Oxford: Oxford University Press; 1991. p. 19-48.

Atkinson CT, Greiner EC, Forrester DJ. Pre-erythrocytic development and associated host responses to Haemoproteus meleagridis (Haemosporina: Haemoproteidae) in experimentally infected domestic turkeys. J Protozool 1986; 33(3): 375-381. PMid:3091815.

Baker JR. Biology of the trypanosomes of birds. In: Lumsden WHR, Evans DA. Biology of the Kinetoplastida. New York: Academic Press; 1976. p. 131-174.

Beaudoin RL, Applegate JE, Davis DE, McLean RG. A model for the ecology of avian malaria. J Wildl Dis 1971(1); 7: 5-13. PMid:4400360.

Bennett GF, Borrero JIH. Blood parasites of some birds from Colombia. $J$ Wildl Dis 1976; 12(3): 454-458. PMid:16498894.

Bennett GF, Souza O. Blood parasites of some birds from São Paulo, Brazil. Mem Inst Oswaldo Cruz 1980; 75(1-2): 117-134. http://dx.doi. org/10.1590/S0074-02761980000100012

Bennett GF, Aguirre AA, Cook RS. Blood parasites of some birds from northeastern Mexico. J Parasitol 1991; 77(1): 38-41. PMid:1992093. http://dx.doi.org/10.2307/3282552

Bennett GF, Whiteway MA, Woodworth-Lynas CB. Host-parasite catalogue of the avian haematozoa. Mem Univ Newfoundland Occ Pap Biol 1982; 5: 1-243.

Bennett GF, Witt H, White EM. Blood parasites of some Jamaican birds. J Wildl Dis 1980; 16(1): 29-38. PMid:6768902.

Comitê Brasileiro de Registros Ornitológicos. CBRO 2006 [cited 2008 Fev. 04]. Available from: http://www.cbro.org.br/CBRO/index.htm

Comitê Brasileiro de Registros Ornitológicos. CBRO 2007 [cited 2008 Fev. 04]. Available from: http://www.cbro.org.br/CBRO/index.htm

Durrant KL, Beadell JS, Ishtiaq F, Graves GR, Olson SL, Gering E, et al. Avian hematozoa in South America: a comparison of temperate and tropical zones. Ornithol Monogr 2006; 60: 98-111. http://dx.doi. org/10.1642/0078-6594(2006)60[98:AHISAA]2.0.CO;2
Fallis AM, Desser SS, Kahn RA. On species Leucocytozoon. Adv Parasitol 1974; 12: 1-67. http://dx.doi.org/10.1016/S0065308X(08)60386-3

Fecchio A, Marini MÂ, Braga ÉM. Baixa prevalência de hemoparasitos em aves silvestres no Cerrado do Brasil Central. Neotrop Biol Conserv 2007; 2(3): 127-135.

Fecchio A, Lima MR, Silveira P, Braga ÉM, Marini MÂ. High prevalence of blood parasites in social birds from a neotropical savanna in Brazil. Emu 2011; 111: 132-138. http://dx.doi.org/10.1071/MU10063

Friend M, Franson JC. Field manual of wildlife diseases: general field procedures and disease of birds. Madison: U. S. Geological Survey Information and Technology Report; 1999.

Garvin MC, Remsen Junior JV. An alternative hypothesis for heavier parasite loads of brightly colored birds: exposure at the nest. Auk 1997; 114(2): 179-191.

Gilardi KVK, Lowenstine LJ, Gilardi JD, Munn CA. A survey for selected viral, chlamydial, and parasitic diseases in wild Dusky-headed Parakeets (Aratinga weddellii) and Tui Parakeets (Brotogeris sanctithomae) in Peru. $J$ Wildl Dis 1995; 31(4): 523-528. PMid:8592384.

Greiner EC, Bennett GF, White E, Coombs RF. Distribution of the avian haematozoa of North America. Can J Zool 1975; 53: 1762-1787. PMid:1212636. http://dx.doi.org/10.1139/z75-211

Hamilton WD, Zuk M. Heritable true fitness and bright birds: A role for parasites? Science 1982(4570); 218: 384-387. PMid:7123238. http://dx.doi.org/10.1126/science.7123238

Kirkpatrick CE, Suthers HB. Epizootiology of blood parasite infections in passerine birds from central New Jersey. Can J Zool 1988; 66(11): 2374-2382. http://dx.doi.org/10.1139/z88-352

Kirkpatrick M, Ryan MJ. The evolution of mating preferences and the paradox of the lek. Nature 1991; 350: 33-38. http://dx.doi. org/10.1038/350033a0

Lainson R, Shaw JJ, Humphrey PS. Preliminary survey of blood-parasites of birds of the Area de Pesquisas Ecológicas do Guamá. Belém, Pará, Brasil. J Parasitol 1970; 56 (Sect. II, Part I): 197-198.

McCallum H, Dobson H. Detecting disease and parasite threats to endangered species and ecosystems. Trends Ecol Evol 1995; 10(5): 190-194. http://dx.doi.org/10.1016/S0169-5347(00)89050-3

McKeand JB. Molecular diagnosis of parasitic nematodes. Parasitology 1998; 117: 87-96. http://dx.doi.org/10.1017/ S0031182099004096

Margolis LG, Esch W, Holmes JC, Kuris AM, Schad G. The use of ecological terms in parasitology. J Parasitol 1982; 68: 131-133. http:// dx.doi.org/10.2307/3281335

Marini MÂ, Reinert BL, Bornschein MR, Pinto JC, Pichorim MA. Ecological correlates of ectoparasitism on Atlantic Forest birds, Brazil. Ararajuba 1996; 4: 93-102.

Merino S, Moreno J, Vásquez RA, Martínez J, Sánchez-Monsálvez I, Estades CF, et al. Haematozoa in forest birds from southern Chile: Latitudinal gradients in prevalence and parasite lineage richness. Austr Ecol 2008; 33(3): 329-340. http://dx.doi.org/10.1111/j.14429993.2008.01820.x

Paul REL, Ariey F, Robert V. The evolutionary ecology of Plasmodium. Ecol Let 2003; 6: 866-880. 
Peirce MA. The significance of avian haematozoa in conservation strategies. In: Cooper J E. Disease and threatened birds. Cambridge: ICBP Technical Publication; 1989. p. 69-76.

Piersma T. Do global patterns of habitat use and migration strategies co-evolve with relative investments in immunocompetence due to spatial variation in parasite pressure? Oikos 1997; 80(3): 623-631. http://dx.doi. org/10.2307/3546640

Pruett-Jones SG, Pruett-Jones MA, Jones HI. Parasites and sexual selection in birds of paradise. Amer Zool 1990; 30(2): 287-298.

Pruett-Jones SG, Pruett-Jones MA, Jones HI. Parasites and sexual selection in a New Guinea avifauna. In: Johnston RF Current Ornithology. New York: Plenum Press; 1991. v. 8, p. 213-245.

Sehgal RNM, Jones HI, Smith TB. Molecular evidence for host specificity of parasitic nematode microfilariae in some African rainforest birds. Mol Ecol 2005; 14(13): 3977-3988. PMid:16262853. http://dx.doi. org/10.1111/j.1365-294X.2005.02555.x

Silveira P, Belo NO, Rodello D, Pinheiro RT, Braga ÉM. Microfilariae infection in wild birds from the Brazilian Cerrado. J Wildl Dis 2010; 46: 1305-1309. PMid:20966285.
Van Riper III C, Van Riper SG, Goff ML, Laird M. The epizootiology and ecological significance of malaria in Hawaiian land birds. Ecol Monogr 1986; 56: 327-344. http://dx.doi.org/10.2307/1942550

White EM, Greiner EC, Bennett GF, Herman CM. Distribution of the haematozoa of Neotropical birds. Rev Biol Trop 1978; 26: 43-102. PMid:108771.

Wilson K, Bjornstad ON, Dobson AP, Merler S, Poglayen G, Randolph SE, et al. Heterogeneities in macroparasites infections: patterns and processes. In: Hudson PJ, Rizzoli A, Grenfell BT, Heesterbeek H, Dobson AP. The ecology of wildlife diseases. Oxford: Oxford University Press; 2002. p. 6-44.

Woodworth-Lynas CB, Caines JR, Bennett GF. Prevalence of avian haematozoa in São Paulo, Brazil. Mem Inst Oswaldo Cruz 1989; 84: 515-526. http://dx.doi.org/10.1590/S0074-02761989000400009

Young BE, Garvin MC, McDonald B. Blood parasites in birds from Monteverde, Costa Rica. J Wildl Dis 1993; 29(4): 555-560. PMid:8258853. 